\title{
MORTE, SUICÍDIO E LUTO - ESTUDOS GESTÁLTICOS, 2008
}

\author{
(Karina Fukumitsu \& Hugo Oddone, Orgs.) \\ Campinas: Livro Pleno
}

ROGÉRIO FERREIRA GONÇALVES

Instituto de Treinamento e Pesquisa em Gestalt-Terapia de Goiânia (ITGT)

Nesta obra, a professora, psicóloga, gestalt-terapeuta e psicopedagoga Karina Okajima Fukumitsu, une seus conhecimentos aos de Hugo Ramón Barbosa Oddone, também psicólogo e gestalt-terapeuta, e juntos engendram um novíssimo trabalho seguindo a abordagem gestalt-terapêutica, onde a temática da morte é tratada de forma não preconceituosa e livre de tabus, fazendo o leitor refletir - como ser de relação que é - sobre aspectos que abrangem vida e morte como complementares, e não antagônicas.

Preocupados em produzir um trabalho rico em contribuições recentes sobre a temática, convidam alguns dos maiores estudiosos da área que, a partir de experiências práticas, tanto profissionais, quanto pessoais (o que torna o trabalho inédito) descortinam os meandros do velado medo do desconhecido, presente na morte.

Assim, logo no primeiro capítulo, Morte e processo de luto: Lições para o recomeço da vida, Karina Okajima Fukumitsu se utiliza de situações reais de atendimentos psicoterapêuticos para evidenciar a importância do processo de luto como fechamento da situação inacabada que é a morte de um ente querido. Em sua intervenção, trabalha a consciência da finitude como caminho para a re-significação da vida, tendo o terapeuta a tarefa de confirmar e acolher os sentimentos oriundos da perda.

Em seguida, Hugo Ramón Barbosa Oddone traz um assunto delicado, considerado pela maioria das pessoas a maior das dores, que é $A$ perda do filho. Neste capítulo levanta as diferenças entre os estilos de elaboração de luto entre pais e mães, bem como a dificuldade de expressão da dor entre o casal, levando em muitos casos à separação após a morte do filho. Defende ainda a possibilidade de o casal apoiar e unir-se na dor, com o respeito à profundidade da dor do outro e vivência da própria, para que haja crescimento.

Incentivada pelo seu profundo interesse pela temática da morte, Eleonôra Torres Prestrelo, no capítulo: Vida e morte: a dialética do humano sob uma perspectiva ges- táltica, traz à tona a difícil e "estranha" tarefa de ser uma terapeuta de pessoas que estão morrendo, na contramão de uma cultura que tenta de forma ilusória controlar o destino, lutando contra a morte antes mesmo de sua proximidade.

Em Reflexões sobre nossa finitude: agrupar pessoas pode gerar mudanças de atitude, Gláucia Rezende Tavares nos convida a humanizarmo-nos a partir da certeza da morte, e traz sua rica experiência como fundadora e presidente da API - Apoio a Perdas Irreparáveis, onde a partir da socialização da dor, pessoas que perderam entes queridos, inclusive a própria autora (que perdeu sua filha com idade de 18 anos) cuidam e são cuidadas, ouvindo e re-significando suas dores, avançando a partir das perdas.

No capítulo O suicídio na cultura japonesa, Heidi Hirano nos brinda com um brilhante e aprofundado estudo sobre o valor moral do suicídio (Seppuku e Harakiri) na cultura japonesa e contextualiza o terapeuta à história particular do povo oriental, fazendo um passeio histórico até os dias atuais e esclarecendo a forma particular com que esta cultura lida com a morte.

Em Falando de morte com crianças, Juliana Martins de Mattos, a partir de sua larga experiência na área hospitalar, versa sobre a dificuldade dos adultos diante da necessidade em dialogar sobre morte com crianças e adolescentes. A autora defende a importância de conversar francamente sobre o tema com as mesmas, porém, respeitando a etapa do desenvolvimento e suas características individuais, superando a mentira cultural de que precisamos proteger nossas crianças da dor e da tristeza, e favorecendo uma visão de morte não como inimiga, mas como complementar à vida.

Por fim, Fernando de Lucca encerra o livro com o capítulo Mantiendo la mente abierta, onde reflete sobre a morte e sofrimento com nuances budistas tibetanas, xamanistas e neo-xamanistas, nos presenteando com suas correlações e nos instigando a transcender nossos conhecimentos. 
Este livro nos convida de forma bela, elegante e lúcida, a pensar e discutir a morte sob um ângulo novo, colorido pela vida, não enegrecido pela mortalha, valorizando os dias, as relações e o tempo.

\section{Referências Bibliográficas}

Fukumitsu, K. O. \& Oddone, H. R. B. (Orgs.) (2008). Morte, suicídio e luto: estudos gestálticos. Campinas: Livro Pleno.

Recebido em 10.05 .08

Aceito em 15.06.08 